\title{
Optimization Sugarcane and Paddy Waste as Bio-Composite Material to Absorb Impact Force
}

\author{
Anis Arendra*, Rifky Yusron, and Teguh Prasetyo \\ Department of Mechanical Engineering, University of Trunojoyo Madura, Bangkalan, Indonesia
}

\begin{abstract}
Agricultural waste such as sugarcane and paddy are common during harvesting to production process. Sometimes they burned after the harvest process, as consequently the environmental problem got multiply. Demand for Composite Material got inflate recently, because they are lighter and stronger than Polyethylene Plastic. Filler in composite materials is expensive and requires precise design. The aim of this research is to create cheap and eco-friendly composite materials, besides raised value of agricultural waste. The composite material using sugarcane bagasse as fibre, paddy chaff powder applied as filler and polyester resin as matrix. In this study, we varied the fibre direction with composition of sugarcane bagasse and paddy chaff powder. In this research fibre direction has three levels they are 0, 45 and 90 degrees. Composition between sugarcane bagasse, paddy chaff powder and polyester resin ratio has three levels they are 15:15:70, 12.5:12.5:75 and 10:10:80. ANOVA test shown fibre direction has significant influence to ability of the material to absorb impact energy 78.14 percent than fibre composition 12.10 percent. The highest impact absorb value is 0.3 degrees Joule on composition ratio paddy chaff: sugarcane: polyester resin is $15: 15: 70$ and 45 degrees fibre direction.
\end{abstract}

Keywords: Bio-Composite, eco-friendly, ANOVA

\section{Introduction}

Sugarcane bagasse (SCB) is waste during sugar production process. Predicted in 2025 sugar production about 3.2 million ton, estimated half mass of them is wasted that called sugarcane bagasse [1]. Rise is essential need for Indonesian people, because major of Indonesian people consuming rice. Demand of rice in Indonesia increasing followed by demography growth. Currently Indonesia production about 70 million ton rice and contributes as much as $9.52 \%$ of total global rice production. Then nominated as big three in production rice [2]. Paddy chaff (PCF) is residue from rice harvesting and their weight is quarter from paddy [3]. Stock of both waste materials are plentiful. Usually both abandon or burned after harvest or production process. That releasing carbon dioxide into air, and have contribution on pollution, and this may release about $2091 \mathrm{CO}_{2} \mathrm{lb}$ gas per each ton [4]. Some research trying from SCB and PCF potency.

Unsaturated polyester resin has well mechanical strength and cheap [5]. In chemical perspective they have some advantage such as good adhesion, good heat transfer, chemicals, and acids resistance, forms good composites with wood, metal, glass fibre, plastics, and natural fibres [6]. Besides its advantages, polyester also has weaknesses, including lower strain value than epoxy resin, lower flame and heat resistance properties than phenolic resins [7]. The addition of an enormous amount of catalyst will cause excessive heat during the curing process [8]. For long term resin can release emission foun in coating material for copper wires in electric motors. detecting releasing alcoholic degradation products induced by the hemiacetal formation [9].

\section{Literature Review}

Research observed paddy chaff as aggregate material in concrete. Variable observed are presentation of paddy chaff on concrete mixing and age of concrete after casting. The variable on presentation paddy chaff is five level from $0 \%$ to $15 \%$. Age after casing variable has two level 7 days and 28 days. Where 7 days presenting concrete has steady strength after casing, then 28 days presenting permanent strength after casting. The result after conducted split and compressive tensile strength show that concrete who combined with paddy chaff USD 33,7 cheaper than conventional concrete [10] and it confirmed in another research [11]. SCB also increasing density of material soil block [12].

Another research investigating about mechanical behaviour on unsaturated polyester resin. Resin material formed from low viscosity type UP-973STV

\footnotetext{
* Corresponding author : anis.arendra@trunojoyo.ac.id
} 
unsaturated polyester resin and curing agent is cobalt octoate accelerator MEKP. specimen geometry $15 \times 25 \times 6$ $\mathrm{mm}$. Tensile stress and strain at failure of the neat resin was found $63 \mathrm{MPa}$ and $4.7 \%$ respectively. Fracture toughness, KIc, and fracture energy, GIc, obtained for the polyester resin lie between the typical values for epoxy resins and polystyrene, which was found 0.30 $\mathrm{MPa} \mathrm{m} 0.5$ and $90 \mathrm{~J} / \mathrm{m} 2$ respectively. Flexural stress and flexural strain at failure of the neat resin was found 78 $\mathrm{MPa}$ and $1.8 \%$ respectively [13].

Reported on research using bio-composite such as rice, wheat and mustard for acoustic absorber for industrial noise control. Rice straw pulp was used in this method, pulp was extracted from rice straw then it was combined with binders to form bio composites. Porosity is highest when rice straw pulp was mixed with natural binders. The best hardness and thermal resistance were from cement and lime binders and moisture content was. Combination bio-composite from rice straw pulp with natural binders have better capability to absorbs sound wave [14].

Another research observed effectivity level on vibroisolation composite biodegradable poly-lactid acid. This research using natural flax fibre as filler, and variate moisture content. Composite material testing bending and tensile. And these natural based vibro-isolation will compare with commercial grade. It has been proven that the type of the plasticizer used in the composite changes the vibro-isolation parameter. The result show that also length and weight $\%$ of fibre had influence of the fibres results in lower material damping values[15]

\section{Methods}

\subsection{Material and Variable}

In this research we using 157 BQTN-EX7 unsaturated polyester resin, with curing agent MEKP. Sugarcane bagasse dried for 10 days with $69-71 \%$ humidity. Grinded paddy chaff dried for 10 days with humidity about 44-48\%. Humidity measures using BALECHECK series 200. Acrylic dice with glass base.

Research variable are fibre direction and fibre composition. Fibre direction (FD) has three level, $0^{\circ}$, $45^{\circ}, 90^{\circ}$. Fibre composition (FC) from total composite weight. Each combination had three replications, that shown in Table 1.

Table 1. Research Variable

\begin{tabular}{|c|c|c|c|}
\hline \multirow{2}{*}{ Fibre Direction } & \multicolumn{3}{|c|}{ Fibre Composition (\%) } \\
\cline { 2 - 4 } & SCB & PCF & PR \\
\hline $45^{\circ}$ & 15 & 15 & 70 \\
\hline $45^{\circ}$ & 12.5 & 12.5 & 75 \\
\hline $45^{\circ}$ & 10 & 10 & 80 \\
\hline $90^{\circ}$ & 15 & 15 & 70 \\
\hline $90^{\circ}$ & 12.5 & 12.5 & 75 \\
\hline $90^{\circ}$ & 10 & 10 & 80 \\
\hline $180^{\circ}$ & 15 & 15 & 70 \\
\hline $180^{\circ}$ & 12.5 & 12.5 & 75 \\
\hline $180^{\circ}$ & 10 & 10 & 80 \\
\hline
\end{tabular}

\subsection{Research Flow}

Research starts from mixing material Process to create composite start from cutting SCB into specific size, then SCB drying in allocated time and humidity measured using Measure Humidity. PCF pounded into being powder. fibre direction is determined based on the research variable, then sprinkled PCF over SCB. Followed by moulding according to ASTM-D6110 length wide and beam 130x130x13 mm size. the process of inserting by means of resin infusion in which the resin is inserted into the mould which is already filled with SCB and PCF and then the PR is inserted by infusing it into the mould. Each specimen is tested for its ability to absorb imp act forces using CHARPY impact test. Final step is observed variable who have significant to absorb impact energy using ANOVA.

\section{Result}

The result from impact test shown on table 2 .

Table 2. Impact test Result

\begin{tabular}{|c|c|c|c|c|c|c|}
\hline \multirow{2}{*}{$\begin{array}{c}\text { Fibre } \\
\text { Direction }\end{array}$} & \multicolumn{3}{|c|}{$\begin{array}{c}\text { Fibre Composition } \\
\text { (\%) }\end{array}$} & \multicolumn{3}{c|}{ Impact Test Result } \\
\cline { 2 - 7 } & SCB & PCF & PR & R1 & R2 & R3 \\
\hline $45^{\circ}$ & 15 & 15 & 70 & 0.20 & 0.29 & 0.19 \\
\hline $45^{\circ}$ & 12.5 & 12.5 & 75 & 0.32 & 0.31 & 0.21 \\
\hline $45^{\circ}$ & 10 & 10 & 80 & 0.28 & 0.33 & 0.21 \\
\hline $90^{\circ}$ & 15 & 15 & 70 & 0.23 & 0.27 & 0.22 \\
\hline $90^{\circ}$ & 12.5 & 12.5 & 75 & 0.21 & 0.28 & 0.30 \\
\hline $90^{\circ}$ & 10 & 10 & 80 & 0.26 & 0.25 & 0.28 \\
\hline $180^{\circ}$ & 15 & 15 & 70 & 0.20 & 0.20 & 0.23 \\
\hline $180^{\circ}$ & 12.5 & 12.5 & 75 & 0.24 & 0.24 & 0.21 \\
\hline $180^{\circ}$ & 10 & 10 & 80 & 0.22 & 0.22 & 0.18 \\
\hline
\end{tabular}

From data in Table 2 then we took hypothesis of ANOVA test for response of composite material to absorb impact energy.

Hypothesis of ANOVA test for influence of the FD factor:

- $\mathrm{H}_{0}$ : There is no significant effect on orientation of fibre direction toughness value of composite material to absorb impact energy

- $\mathrm{H}_{1}$ : There is a significant influence on orientation of the fibre direction on toughness value of composite materials to absorbing impact energy

Hypothesis of ANOVA test for influence of the FC factor:

- $\mathrm{H}_{0}$ : There is no significant effect on fibre composition on toughness value of of composite material to absorb impact energy

- $\mathrm{H}_{1}$ : There is a significant influence on fibre composition on toughness value of composite materials to absorbing impact energy

There question for processing data from impact test result to find which variable more significant than another variable:

Factor correction

$F_{c}=\left(\sum_{i} \sum_{j} Y_{i j}\right)^{2} / r \cdot a \cdot b$

Sum Square 


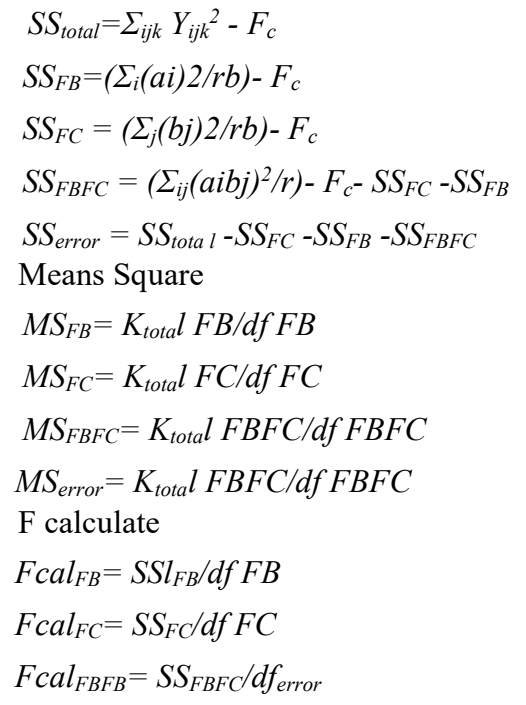

Table 3 shows data processing of toughness value of biocomposite materials in absorbing impact energy.

Table 3. Anova Test result.

\begin{tabular}{|c|c|c|c|c|c|c|}
\hline Source & SS & $\mathbf{D f}$ & $\mathbf{M S}$ & $\mathbf{F}_{\text {cal }}$ & $\mathbf{p}_{\text {val }}$ & $\mathbf{F}_{\text {tab }}$ \\
\hline Fibre & 0,02 & 2 & 0,0121 & 12,10 & 0.000 & 3,554 \\
Direction & 4207 & & 03704 & 3703 & 4666 & 55714 \\
& 407 & & & & 104 & 6 \\
\hline Fibre & 0,00 & 2 & 0,0026 & 2,625 & 0,099 & 3,554 \\
Composi & 5251 & & 25926 & 9259 & 8469 & 55714 \\
tion & 852 & & & 26 & 08 & 6 \\
\hline $\begin{array}{c}\text { Intereacti } \\
\text { on }\end{array}$ & 0,00 & 4 & 0,0007 & 0,000 & 0,551 & 2,927 \\
& 3125 & & 81481 & 7814 & 8015 & 74417 \\
26 & & & 81 & 24 & 3 \\
\hline Error & 0,01 & 18 & 0,001 & & & \\
& 8 & & & & & \\
\hline Total & 0,05 & 26 & & & & \\
& 0584 & & & & & \\
\hline
\end{tabular}

After conducting ANOVA test, to make sure there is data have normal spread and acceptable by statistic perspective. Result of normality test shown on table 4 .

Table 4. Normality test result

\begin{tabular}{|c|c|c|c|}
\hline $\begin{array}{c}\text { Normality Test } \\
\text { Type }\end{array}$ & Stat & df & Sig \\
\hline $\begin{array}{c}\text { Kalmogorov- } \\
\text { Smimova }\end{array}$ & $\begin{array}{c}0.1274471 \\
55\end{array}$ & 27 & 0.2 \\
\hline Shapio-Wilk & 0.947074 & 27 & 0.181908 \\
\hline
\end{tabular}

Based on data from table 4 we can see significant value from fibre capability to absorb impact test result about 0.2 , which is higher that $\alpha=0.05$. it's mean that we are accept $\mathrm{H}_{0}$ and all data level has distributed normally. We can conclude residual data has distributed normal and meet ANOVA test assumption. Final test is uji turkey on FD to find which treatment on variable FD have most significant value, hat shown on table 5 .
Table 5. Anova Test result.

\begin{tabular}{|c|c|c|c|c|c|c|}
\hline \multirow{2}{*}{$\begin{array}{l}\text { (I) } \\
\text { FD }\end{array}$} & \multirow{2}{*}{$\begin{array}{l}(J) \\
\text { FD }\end{array}$} & \multirow{2}{*}{$\begin{array}{c}\text { Mean } \\
\text { (i-J) }\end{array}$} & \multirow{2}{*}{$\begin{array}{c}\text { Std } \\
\text { Error }\end{array}$} & \multirow{2}{*}{ Sig } & \multicolumn{2}{|c|}{$\begin{array}{c}95 \% \text { interval } \\
\text { confidence }\end{array}$} \\
\hline & & & & & $\begin{array}{c}\text { Low } \\
\text { bound }\end{array}$ & $\begin{array}{l}\text { High } \\
\text { bound }\end{array}$ \\
\hline \multirow[t]{2}{*}{$180^{\circ}$} & 45 & $-0,02$ & $\begin{array}{c}0,0149 \\
07\end{array}$ & $\begin{array}{l}0,3913 \\
81\end{array}$ & $-0,058$ & $\begin{array}{l}0,0180 \\
45\end{array}$ \\
\hline & 90 & $\begin{array}{c}0,0511 \\
11\end{array}$ & $\begin{array}{c}0,0149 \\
07\end{array}$ & $\begin{array}{c}0,0080 \\
1\end{array}$ & $\begin{array}{l}0,0130 \\
66\end{array}$ & $\begin{array}{c}0,0891 \\
57\end{array}$ \\
\hline \multirow[t]{2}{*}{$45^{\circ}$} & 180 & 0,02 & $\begin{array}{c}0,0149 \\
07\end{array}$ & $\begin{array}{l}0,3913 \\
81\end{array}$ & $-0,018$ & $\begin{array}{l}0,0580 \\
45\end{array}$ \\
\hline & 90 & $\begin{array}{c}0,0711 \\
11\end{array}$ & $\begin{array}{c}0,0149 \\
07\end{array}$ & $\begin{array}{c}0,0004 \\
29\end{array}$ & $\begin{array}{l}0,0330 \\
66\end{array}$ & $\begin{array}{c}0,1091 \\
57\end{array}$ \\
\hline \multirow[t]{2}{*}{$90^{\circ}$} & 180 & $\begin{array}{c}-0,05 \\
111\end{array}$ & $\begin{array}{l}0,0149 \\
07\end{array}$ & $\begin{array}{c}0,0080 \\
1\end{array}$ & $\begin{array}{c}-0,089 \\
16\end{array}$ & $\begin{array}{l}-0,013 \\
07\end{array}$ \\
\hline & 45 & $\begin{array}{c}-0,071 \\
11\end{array}$ & $\begin{array}{c}0,0149 \\
07\end{array}$ & $\begin{array}{c}0,0004 \\
29\end{array}$ & $\begin{array}{c}-0,109 \\
16\end{array}$ & $\begin{array}{c}-0,033 \\
07\end{array}$ \\
\hline
\end{tabular}

Based on data on table 5 shown that the only two level on variable fibre direction had significant value more than 0.05 both of them are fibre direction $45^{\circ}$ and $180^{\circ}$.

\section{Discussion}

Based on the calculation, it is found that the F count for the FD factor is 12.10 with the F table value of 3.55 so it is said that the F count is greater than the F table so that $\mathrm{H} 0$ is rejected. FD treatment has a significant effect on the toughness value of composite materials in absorbing impact energy. In addition, the calculated $\mathrm{F}$ for the FC factor is 2.63 with the $\mathrm{F}$ table value of 3.55 so it is said that the calculated $\mathrm{F}$ is smaller than the $\mathrm{F}$ table so that we accept $\mathrm{H}_{0}$. FC variable there is no significant effect on the value of the toughness of the composite material in absorbing impact energy [16]. Based on the calculation, it was found that the calculated $F$ for the interaction between the orientation of the fibre direction and the percentage composition was 0.78 with an $\mathrm{F}$ table value of 2.93 so it was said that the calculated $\mathrm{F}$ was smaller than the $\mathrm{F}$ table so that $\mathrm{H} 0$ was accepted. From the interaction between the orientation of the fibre direction and the percentage composition does not have a significant effect on the value of the toughness of the composite material in absorbing impact energy[17]. From the results of calculations on the ANOVA test on the variable direction of fibre and fibre composition has a significant influence on the value of the toughness of composite materials in absorbing impact energy. From the interaction between fibre direction orientation and percentage composition, there is no significant effect on the toughness value of composite materials in absorbing impact energy. The best combination to absorb on this research is composition $15 \%$ sugarcane bagasse, $15 \%$ paddy chaff and $70 \%$ polyester resin with fibre direction $45^{\circ}$. composite on this research have average capability to absorb impact test $0.3^{\circ}$ joule. The direction of the $45^{\circ}$ fibre can mathematically cause the impact force to be 
ineffective up to half[18]. angle of $45^{\circ}$ is also often used to deflect forces in some turbine impeller designs[19] that why it better that $90^{\circ}$ and $180^{\circ}$ to absorb impact energy. [20]

\section{References}

[1] K. Sumada, R. Dewati, and Suprihatin, "Improvement of seawater salt quality by hydro-extraction and re-crystallization methods," J. Phys. Conf. Ser., vol. 953, no. 1, (2018), doi: 10.1088/1742-6596/953/1/012214.

[2] A. Bashir and S. Yuliana, "Identifying factors influencing rice production and consumption in Indonesia," J. Ekon. Pembang. Kaji. Masal. Ekon. dan Pembang., vol. 19, no. 2, (2019), doi: 10.23917/jep.v19i2.5939.

[3] R. Badar and S. A. Qureshi, "Composted rice husk improves the growth and biochemical parameters of sunflower plants," J. Bot., vol. 2014, no. January, (2014), doi: $10.1155 / 2014 / 427648$

[4] E. F. Darley, F. R. Burleson, E. H. Mateer, J. T. Middleton, and V. P. Osterli, "Contribution of burning of agricultural wastes to photochemical air pollution," J. Air Pollut. Control Assoc., vol. 16, no. 12, pp. 685-690, (1966), doi:10.1080/00022470.1966.10468533.

[5] T. Bender, J. Dabrowski, and M. Gagné, "Delineating The Multiple Roles of B(C6F5)3 in the Chemoselective Deoxygenation of Unsaturated Poly-ols," ACS Catal., vol. 6, Nov. (2016), doi: 10.1021/acscatal.6b02551.

[6] Z. Zhang, H. Zhang, T. Liu, and W. Lv, "Study on the micro-mechanism and structure of unsaturated polyester resin modified concrete for bridge deck pavement," Constr. Build. Mater., vol. 289, p. 123174, (2021), doi: https://doi.org/10.1016/j.conbuildmat.2021.123 174.

[7] R. Pignatello et al., "Unsaturated Poly(Hydroxyalkanoates) for the Production of Nanoparticles and the Effect of Cross-Linking on Nanoparticle Features," Materials (Basel)., vol. 12, p. 868, Mar. (2019), doi: $10.3390 / \mathrm{ma} 12060868$.

[8] B. Yang, M. Wu, X. Li, J. Zhang, and H. Wang, "Effects of cold working and corrosion on fatigue properties and fracture behaviors of precipitate strengthened $\mathrm{Cu}-\mathrm{Ni}-\mathrm{Si}$ alloy," Int. J. Fatigue, vol. 116, pp. 118-127, (2018), doi: https://doi.org/10.1016/j.ijfatigue.2018.06.017.

[9] A. Funtan, P. Michael, S. Rost, J. Omeis, K. Lienert, and W. Binder, "Chemosensors: SelfDiagnostic Polymers-Inline Detection of Thermal Degradation of Unsaturated Poly(ester imide)s (Adv. Mater. 18/2021)," Adv. Mater., vol. 33, May (2021), doi: 10.1002/adma.202170140.

[10] P. C. Kumar and P. M. Rao, "A study on reuse of Rice Husk Ash in Concrete," Pollut. Res., vol. 29, no. 1, pp. 157-163, (2010), doi: 10.26480/gwk.01.2019.01.04.

[11] F. Sheikh Khalid, H. S. Herman, and N. B. Azmi, "Properties of Sugarcane Fibre on the Strength of the Normal and Lightweight Concrete," MATEC Web Conf., vol. 103, (2017), doi:10.1051/matecconf $/ 201710301021$.

[12] H. Danso, D. B. Martinson, M. Ali, and J. B. Williams, "Effect of Sugarcane Bagasse Fibre on the Strength Properties of Soil Blocks," 1st Int. Conf. Bio-based Build. Mater., ()2015.

[13] M. Davallo, H. Pasdar, and M. Mohseni, "Mechanical properties of unsaturated polyester resin," Int. J. ChemTech Res., vol. 2, no. 4, pp. 2113-2117, (2010).

[14] A. Fatima et al., "Feasibility of manufacturing sustainable bio-composites from agricultural waste," Mater. Today Proc., (2021), doi: https://doi.org/10.1016/j.matpr.2021.06.260.

[15] Pawlik, Arkadiusz and Frackowiak, Stanislaw, "The vibroisolation effectiveness of fibre reinforced natural composites compared to the elastomer materials produced from nonrenewable resources," E3S Web Conf., vol. 116, p. 59, (2019), doi: 10.1051/e3sconf/201911600059.

[16] Y. Zhang, W. Yu, N. Kim, and Y. Qi, "Mechanical performance and dimensional stability of bamboo fibre-based composite," Polymers (Basel)., vol. 13, no. 11, pp. 1-12, (2021), doi: 10.3390/polym13111732.

[17] G. Chinga-Carrasco, "Novel Biocomposite Engineering and Bio-Applications," Bioengineering, vol. 5, no. 4, (2018), doi: 10.3390/bioengineering5040080.

[18] A. S. Tersenov, "On the fast diffusion with strong absorption," J. Math. Phys., vol. 54, no. 4, p. 41503, Apr. (2013), doi: 10.1063/1.4798792.

[19] P. J. Schubel and R. J. Crossley, "Wind turbine blade design," Energies, vol. 5, no. 9, pp. 34253449, (2012), doi: 10.3390/en5093425.

[20] M. Rajendran and C. kavitha Nagarajan, "Experimental Investigation on bio-Composite Using Jute and Banana Fibre as a Potential Substitute of Solid Wood Based Materials," J. Nat. Fibres, pp. 1-10, Jan. (2021), doi: 10.1080/15440478.2020.1867943. 